\title{
Granitoid-series Evaluation of the Archaean Johannesburg Dome Granitoids, South Africa
}

\author{
Shunso IshiHARA ${ }^{1}$, Carl R. ANHAEUSSER ${ }^{2}$ and Laurence J. RoBB ${ }^{2}$
}

\begin{abstract}
Shunso Ishihara, Carl R. Anhaeusser and Laurence J. RobB (2002) Granitoid-series evaluation of the Archaean Johannesburg Dome granitoids, South Africa. Bull. Geol. Surv. Japan, vol. 53 (1), p. 1 $-9,5$ figs., 3 photographs.
\end{abstract}

\begin{abstract}
Archaean granitoids of the Johannesburg Dome were evaluated in terms of the granitoid series using $\mathrm{Fe}_{2} \mathrm{O}_{3} / \mathrm{FeO}$ ratios of bulk chemistry and magnetic susceptibility measurement. The $\mathrm{Fe}_{2}$ $\mathrm{O}_{3} / \mathrm{FeO}$ ratios range between 0.05 and 0.72 and are generally below 0.5 , implying that they belong mostly to reduced, ilmenite-series granitoids. Magnetic susceptibility was measured on 122 samples of TTG suite granitoids and 239 samples of calc-alkaline suite granitoids collected on the $700 \mathrm{~km}^{2}$ granitic inlier constituting the Johannesburg Dome in the central part of the Kaapvaal Craton, South Africa. From the measurements it was established that the TTG suite consists of $78 \%$ ilmenite -series granitoids and $22 \%$ magnetite-series granitoids, while the calc-alkaline suite consists of $83 \%$ ilmenite-series and $17 \%$ magnetite-series granitic rocks. Magnetite-series granitoids, which are intermediate series in a strict sense, tend to occur sporadically in the central part of the Dome at the interface between the TTG and calc-alkaline granitoids. The granitoids are generally seen to be of a reduced type, the reducing conditions most likely being partly the result of assimilation of the country rocks into which the granitic rocks intruded.
\end{abstract}

\section{Introduction}

Measurement of magnetic susceptibility is a powerful tool in field studies of granitic rocks. The magnetite content can readily be ascertained and provides important information on the redox state of any given granitoids. Magnetic susceptibility studies have been applied to the Phanerozoic granitoids of Japan (Kanaya and Ishihara, 1973; Ishihara, 1979), South Korea (Ishihara et al., 1981; Jin et al., 2001), South and North China (Ishihara and Wang, 1999; Ishihara et al., 2001), the Malay Peninsula (Ishihara et al., 1979), the Lachlan Fold Belt of Australia (Tainosho et al., 1988), the Sierra Nevada batholith (Bateman et al., 1991), the Peninsular Range batholith (Gastil et al., 1990), Northern Chile (Ishihara et al., 1984) and granitoids of coastal Peru (Ishihara et al., 2000). Regional variations have been revealed in these studies that reflect the intrinsic redox state of the granitic magmas.

In this study, magnetic susceptibility investigations were applied to the c.3340-3000Ma Archaean granitic rocks exposed on the Johannesburg Dome situated in the central part of the Kaapvaal Craton in South

\footnotetext{
${ }^{1}$ Institute of Geoscience, GSJ

${ }^{2}$ Economic Geology Research Institute-Hugh Allsopp Laboratory, School of Geosciences, University of the Witwatersrand, Private Bag 3, PO Wits 2050, Johannesburg, South Africa
}

Africa. The Johannesburg Dome, which occurs as an ovoid inlier surrounded by Archaean and Proterozoic sediments and volcanic rocks occupies an area of approximately $700 \mathrm{~km}^{2}$ and constitutes one of a number of domical "windows" of ancient granitic basement on the Kaapvaal Craton(Fig. 1). Susceptibility measurements were performed using a portable KT-5 magnetic susceptibility meter. Measurements were made on fresh rocks available on surface, both in field as well as on an extensive collection of granitoid samples housed at the Economic Geology Research Institute at the University of the Witwatersrand, Johannesburg.

The nature of the rock surface is important when undertaking susceptibility measurements with the portable KT- 5 device. If the surface of the outcrop or measured samples is uneven correction factors need to be applied to normalize the measured values to those obtained on flat surfaces. The following correction factors recommended by the device producer were applied in this study: Surface unevenness $1 \mathrm{~mm}$, correcting factor, $\mathrm{k}=1.07 ; 2 \mathrm{~mm}, \mathrm{k}=1.15 ; 3 \mathrm{~mm}, \mathrm{k}=1.24$; $4 \mathrm{~mm}, \mathrm{k}=1.35 ; 5 \mathrm{~mm}, \mathrm{k}=1.44 ; 6 \mathrm{~mm}, \mathrm{k}=1.55$; and $7 \mathrm{~mm}, \mathrm{k}=1.66$.

The redox state of the Johannesburg Dome granitoids was initially evaluated using published $\mathrm{Fe}_{2}$

Keywords: Johannesburg Dome, magnetic susceptibility, $\mathrm{Fe}_{2} \mathrm{O}_{3} / \mathrm{FeO}$ ratio, magnetite series, ilmenite series, $\mathrm{Ar}$ chaean granitoids 


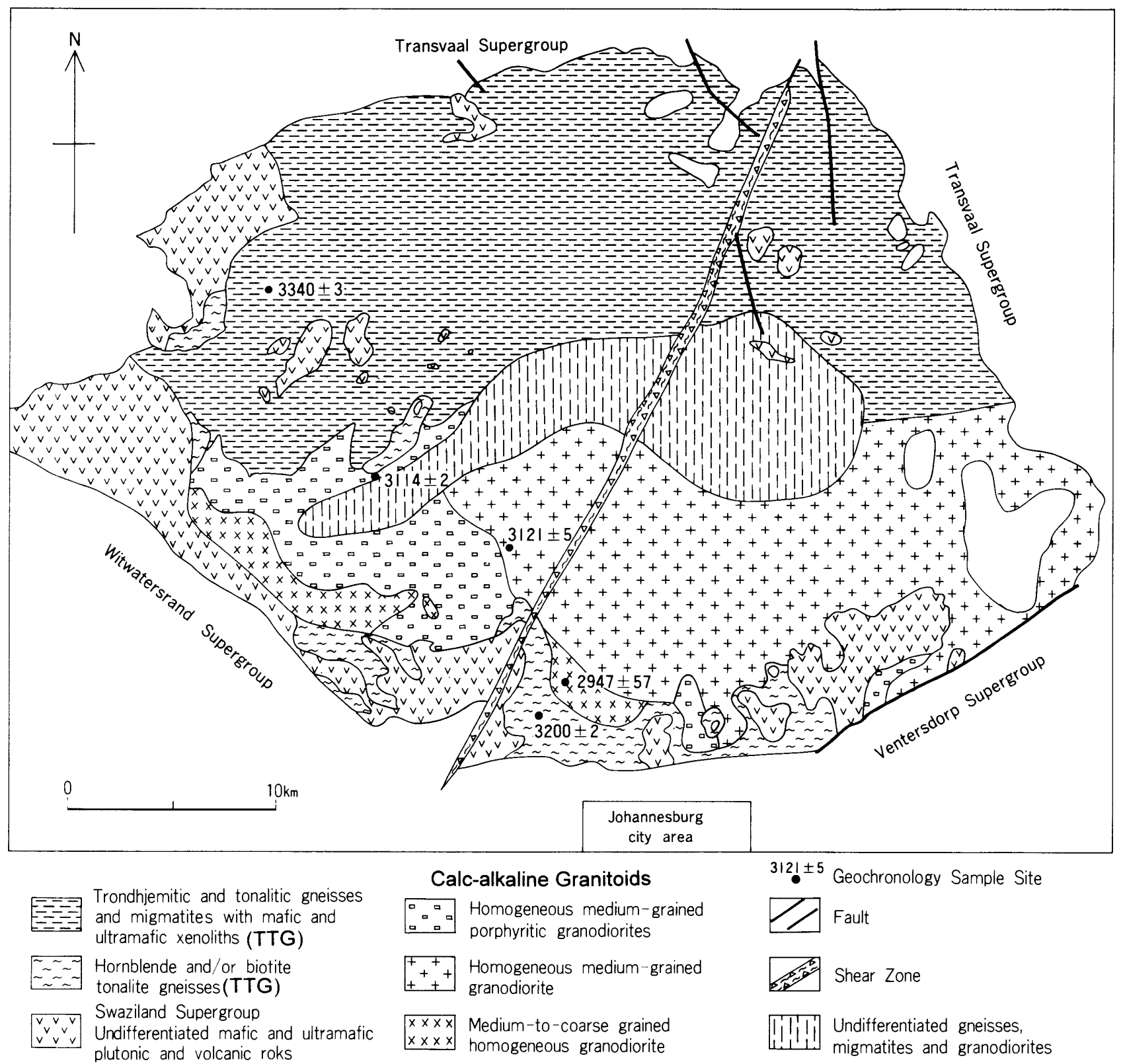

Fig. 1 Simplified geological map of the Johannesburg Dome (modified after Anhaeusser, 1973). U-Pb zircon ages of the main granitoid types on the Dome after Poujol and Anhaeusser (2001).

Blank part is post-granitoids sedimentary and volcanic rocks.

$\mathrm{O}_{3}$ and $\mathrm{FeO}$ data. These results supplement the magnetic susceptibility measurements presented in this paper. It should be noted that the magnetite-and ilmenite-series granitoids, as originally defined by Ishihara (1977), can be distinguished using a separation value of 0.5 of $\mathrm{Fe}_{2} \mathrm{O}_{3} / \mathrm{FeO}$ (wt. \%) (Ishihara et al., 1979) and $3.0 \times 10^{-3}$ units of magnetic susceptibility (Ishihara, 1990), precisely at 70 wt.\% $\mathrm{SiO}_{2}$ (Fig. 2).

\section{Johannesburg Dome Granitoids}

Archaean granitoids on the Kaapvaal Craton are best exposed and widely distributed in the Barberton granite-greenstone terrane located approximately $400 \mathrm{~km}$ east of Johannesburg (Robb and Anhaeusser, 1983). Archaean granitic rocks also occur north of Johannesburg where they intrude the Archaean mafic and ultramafic volcanic and plutonic greenstones in the area (Anhaeusser, 1977, 1978, 1992, 1999). These mafic and ultramafic rocks have been equated with similar rocks found in the Barberton Supergroup (formerly referred to as the Swaziland Supergroup). Anhaeusser (1973) divided the granitic rocks of the Johannesburg Dome into several types (Fig. 1) and further provided bulk chemical analyses, including $\mathrm{Fe}_{2}$ $\mathrm{O}_{3}$ and $\mathrm{FeO}$ contents, for representatives of the 


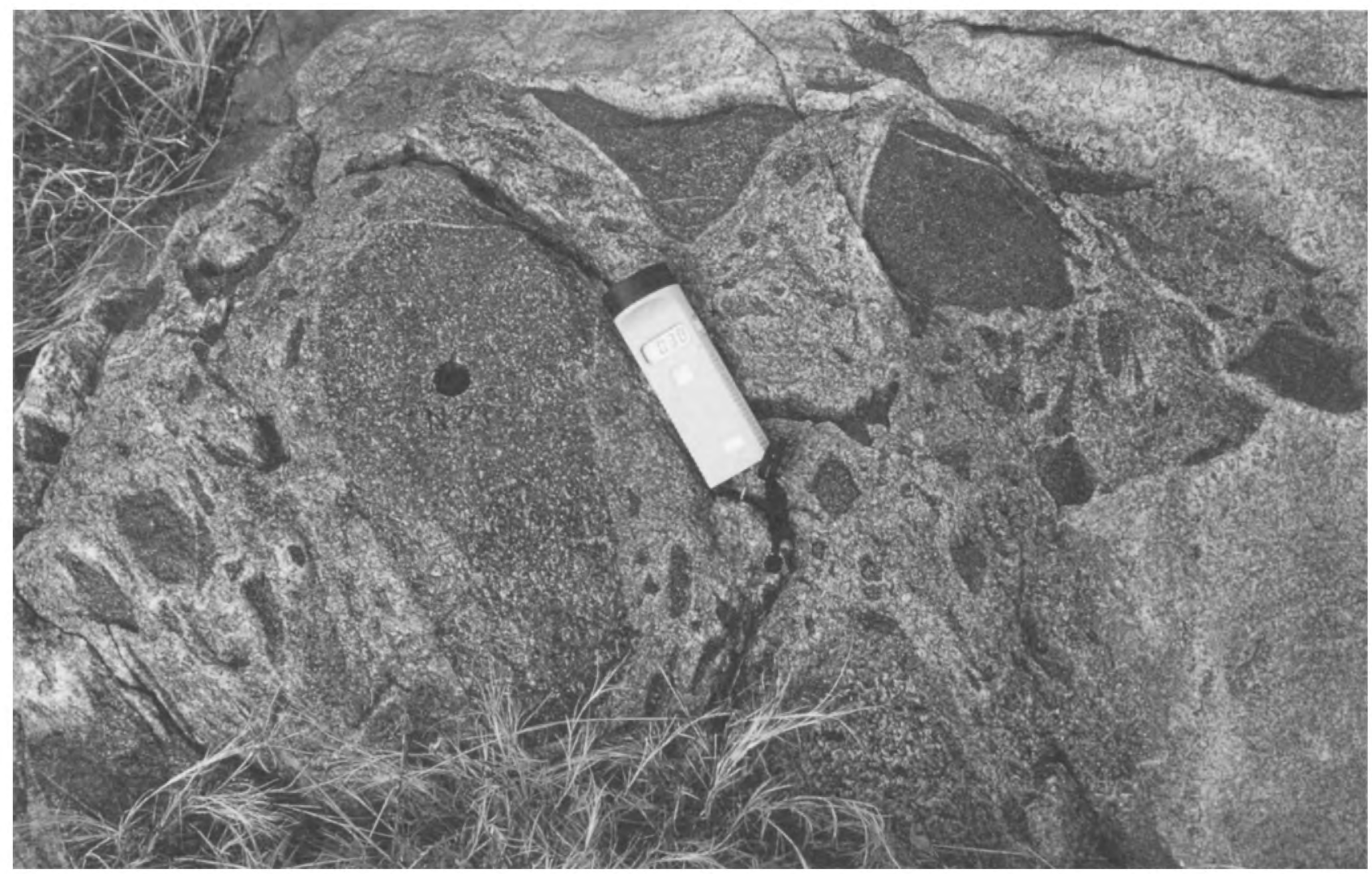

Photograph 1 Heterogeneous Archaean TTG suite rocks exposed on the farm Nooitgedacht, Johannesburg Dome, South Africa. Shown are variably altered (feldspathized) agmatitic remnants of amphibolite in a host matrix consisting mainly of biotite-trondhjemite gneiss (Anhaeusseur, 1999). The magnetic susceptibilities as measured by the portable device in the photograph ( $19.5 \mathrm{~cm} \mathrm{long}$ ) range generally 0.3 to $0.4 \times 10^{-3} \mathrm{SI}$, very locally in mafic facies $3.1 \times 10^{-3} \mathrm{SI}$.

Length of the scale (magnetic suscpetibility meter) is $19.5 \mathrm{~cm}$.

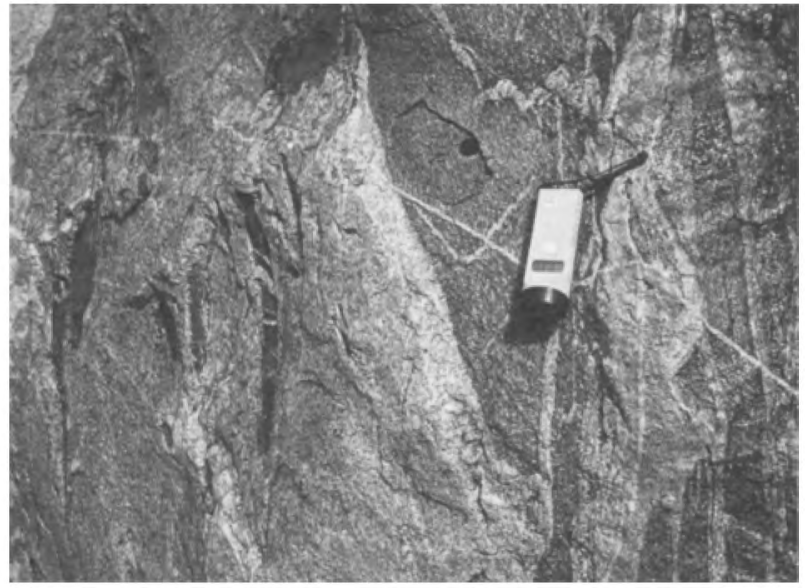

Photograph 2 Heterogeneous Archaean TTG suite rocks exposed on the farm Nooitgedacht, Johannesburg Dome, South Africa. Shown are deformed xenolithic fragments of feldspathized amphibolite (metamorphosed and metasomatised komatiitic basaltic "greenstones") intruded by c. $3.34 \mathrm{Ga}$ tonalitic/trondhjemitic gneisses.

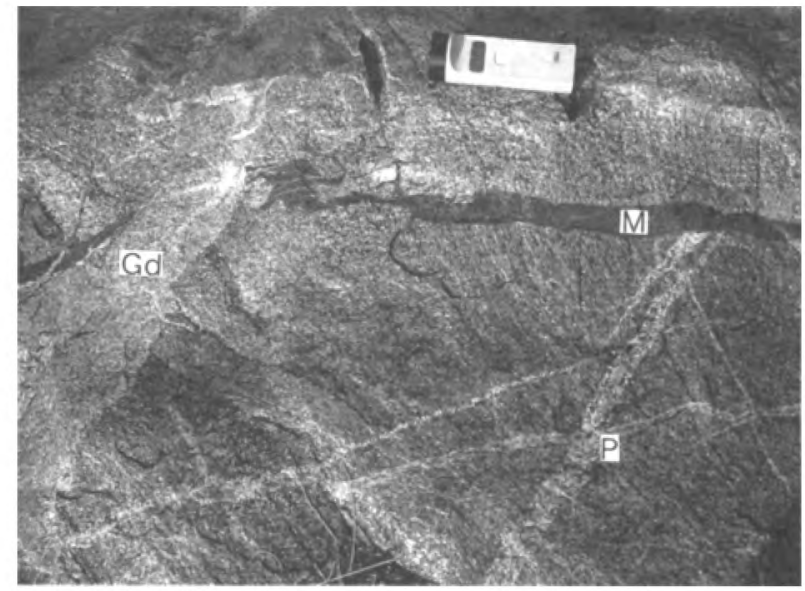

Photograph 3 Foliated trondhjemitic gneiss (c. 3.34 $\mathrm{Ga}$ ) exposed on the farm Nooitgedacht, Johannesburg Dome, South Africa. A thin mafic (amphibolite) dyke (M) intrudes the gneisses and is, in turn, cut by granodioritic (Gd) and pegmatitic dykelets $(\mathrm{P})$ which range in age from 3.12 to 3.00 Ga. 
granitic varieties found on the Dome.

The granitoid rocks of the dome are unconformably overlain by sedimentary rocks of the Witwatersrand Supergroup as well as volcanic and sedimentary rocks of the Ventersdorp and Transvaal Supergroups. Anhaeusser $(1973,1999)$ subdivided the granitic rocks into essentially two varieties: (1) ancient tonalitic gneisses and leuco-trondhjemite-granodiorite gneisses, the so-called "TTG suite" (Photographs 1, 2); and (2) homogeneous, and in places porphyritic granodiorites and adamellites-hereafter termed the "calc-alkaline suite". The tonalitic and trondhjemitic gneisses (Photograph 3), which occupy most of the northern half of the dome as well as areas around the southern margins of the dome (Fig. 1), contain numerous greenstone remnants or xenoliths, together with migmatites produced as a result of granite-greenstone intermixing.

$\mathrm{U}-\mathrm{Pb}$ zircon age determinations by Poujol and Anhaeusser (2001) indicated several stages of granitoid intrusion (refer to Fig. 1): (1) leuco-biotite trondhjemitic gneisses of c.3340 Ma age in the north; (2) c.3200 $\mathrm{Ma}$ hornblende-tonalite gneisses in the far south; (3) calc-alkaline granitoids (granodiorite -adamellite) of c.3120-3114 Ma in the south-central part of the dome; and (4) potassic pegmatites of $\mathrm{c}$. $3000 \mathrm{Ma}$ representing late-stage granitoids associated with the calc-alkaline granitic rocks. The TTG suite includes a variety of biotite- and hornblende-bearing tonalitic and trondhjemitic granitoids and gneisses (Fig. 1), grading locally into dioritic, granodioritic and quartz-dioritic gneisses, and including a variety of metamorphosed and metasomatised mafic and ultramafic rocks (Anhaeusser, 1999). The calc-alkaline suite (i.e., calcic in the sense of Peacock, 1931), whose alkali-lime index has been calculated to be 62 . 5 from the chemical data of Anhaeusser (1973), can be further subdivided into tonalite-granodiorite and granodiorite-granite.

\section{Bulk $\mathrm{Fe}_{2} \mathrm{O}_{3} / \mathrm{FeO}$ Ratios}

The magnetite-series and ilmenite-series granitoids are empirically separated at 0.5 of bulk $\mathrm{Fe}_{2} \mathrm{O}_{3} / \mathrm{FeO}$ ratio on granitic rocks from Japan (Ishihara et al., 1979). It was established that the bulk $\mathrm{Fe}_{2} \mathrm{O}_{3} / \mathrm{FeO}$ ratio of any given granitoids generally increases with increasing of the $\mathrm{SiO}_{2}$ content. Such a trend based on the average chemical compositions of the Japanese granitoids is represented by the curved broken line in Fig. 2. This line with $0.5 \mathrm{Fe}_{2} \mathrm{O}_{3} / \mathrm{FeO}$ at 70 wt. $\% \mathrm{SiO}_{2}$, is considered boundary value of the two series in the following examinations.

Within the TTG suite, the mesocratic hornblende biotite tonalites and tonalitic gneisses have $\mathrm{Fe}_{2} \mathrm{O}_{3}$ /

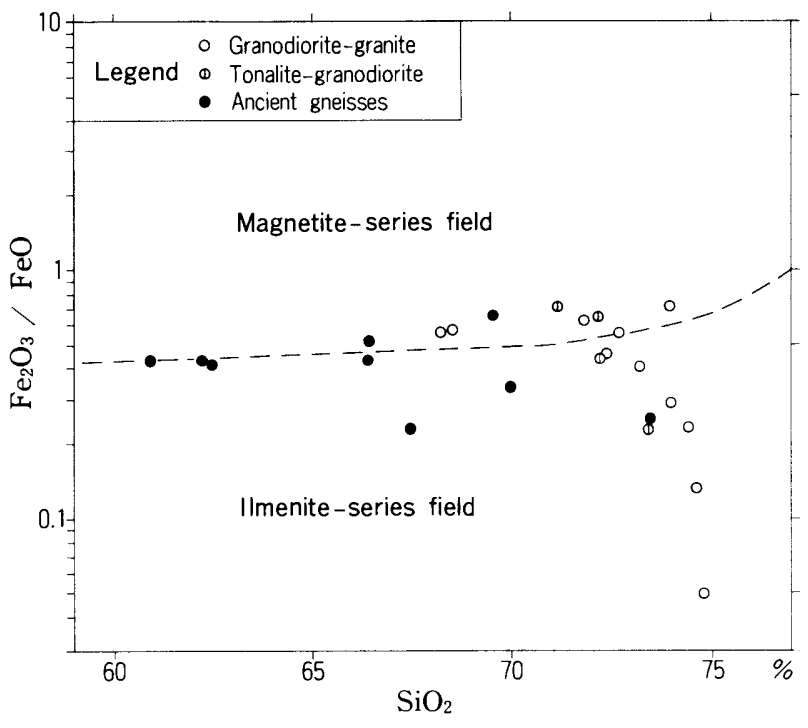

Fig. 2 Plot of $\mathrm{Fe}_{2} \mathrm{O}_{3} / \mathrm{FeO}$ ratios versus $\mathrm{SiO}_{2}$ of the Johannesburg Dome granitoids. Broken line, boundary line for the magnetite-series and ilmenite-series granitoids. For the definition and plotted data, see the text.

$\mathrm{FeO}$ ratios of $0.42-0.43(\mathrm{n}=3$, Table 1 , Anhaeusser, 1973), which are lower than the limiting value of 0.5 . Thus, these gneisses are considered to be part of the ilmenite series. The biotite leuco-tonalitic gneisses and biotite trondhjemites of the northern half of the dome have $\mathrm{Fe}_{2} \mathrm{O}_{3} / \mathrm{FeO}$ ratios of $0.23-0.66(\mathrm{n}=6$, Table 2, Anhaeusser, 1973). Four of these samples show ilmenite-series values $(0.23,0.25,0.34,0.43)$ with two falling into the magnetite-series category $(0.51,0.66)$. Taken together, the TTG rock suite is composed of $78 \%$ ilmenite-series and $22 \%$ magnetite-series rock types $(n=9$, Fig. 2).

The calc-alkaline suite, consisting of homogeneous, medium-to-coarse grained, pinkish-grey granodiorites (in places grading into tonalites, Table 3; Anhaeusser, 1973) have $\mathrm{Fe}_{2} \mathrm{O}_{3} / \mathrm{FeO}$ ratios of $0.23,0.44,0$. 65 and 0.70 . These granitoids comprise equal amounts of ilmenite- and magnetite-series granitoids with a low average $\mathrm{Fe}_{2} \mathrm{O}_{3} / \mathrm{FeO}$ ratio of $0.51 \quad(n=4)$. The homogeneous, medium-grained, grey granodioritic-to -granitic suite (including also the porphyritic granodiorites) have $\mathrm{Fe}_{2} \mathrm{O}_{3} / \mathrm{FeO}$ ratios of $0.05,0.29,0$. 46, 0.55 and 0.72 (Table 4, Anhaeusser, 1973). Thus, they are made up of $60 \%$ ilmenite series and $40 \%$ magnetite series rocks with an average $\mathrm{Fe}_{2} \mathrm{O}_{3} / \mathrm{FeO}$ value of $0.41 \quad(n=5)$. Porphyritic granites, possibly influenced by the intrusion into them of Pilanesberg dykes (Table 5, Anhaeusser, 1973), have $\mathrm{Fe}_{2} \mathrm{O}_{3} / \mathrm{FeO}$ ratios of 0.13 and 0.55 (average $0.34, \mathrm{n}=2$ ).

Between the TTG granitoids in the north and the homogeneous-to-porphyritic calc-alkaline granodior- 
ites in the south-central part of the dome is a zone referred to by Anhaeusser (1973) as a "Transitional -Zone". This transitional or central sector of the dome contains rocks consisting of a mixed zone of mig. matites and gneisses, together with homogeneous and porphyritic granodiorites (i. e., a suite of granitic rocks comprising remnants of both the early-c. 3340 Ma-trondhjemitic gneisses and the later intrusive phases belonging to the c. 3121-3114 Ma granodiorites and porpyritic granodiorites). A number of granitic tors are developed in this central area of the dome. The rocks in the Transitional Zone have low $\mathrm{Fe}_{2} \mathrm{O}_{3} /$ FeO ratios of $0.23,0.40,0.56$ and 0.62 (average $0.45, \mathrm{n}=$ 4, Table 6; Anhaeusser, 1973). Fine-grained foliated diorite from the western edge of the dome (Fig. 1, near the Witwatersrand outlier known as Zwartkop) has a very low $\mathrm{Fe}_{2} \mathrm{O}_{3} / \mathrm{FeO}$ ratio of 0.26 (Table 8 , Anhaeusser, 1973).

As a general conclusion, the $\mathrm{Fe}_{2} \mathrm{O}_{3} / \mathrm{FeO}$ ratios of both the TTG suite (average $0.41 ; n=9$ ) and the calc -alkaline granitoids (average $0.43 ; n=16$ ) are very similar and all these granitic rocks appear to be of a generally reduced character (Fig. 2).

\section{Magnetic Susceptibility}

Measured values of the magnetic susceptibility of the Johannesburg Dome granitoids are shown graphically in Figs. 3 and 4 . Granitoids of the TTG suite occur mainly along the southern margin and in the north-central part of the dome. There is no clear magnetic susceptibility difference between granitoids of the TTG suite and the calc-alkaline suite. The magnetic susceptibility values are, however, lower in the southwestern and southeastern sectors of the dome where the remnants of the mafic and ultramafic greenstones are exposed. Within the granitic terrane, particularly on the northern half of the dome, the greenstones remnants occur as xenoliths and the granitoids in their vicinity tend to record low magnetic susceptibility values. By contrast, high magnetic

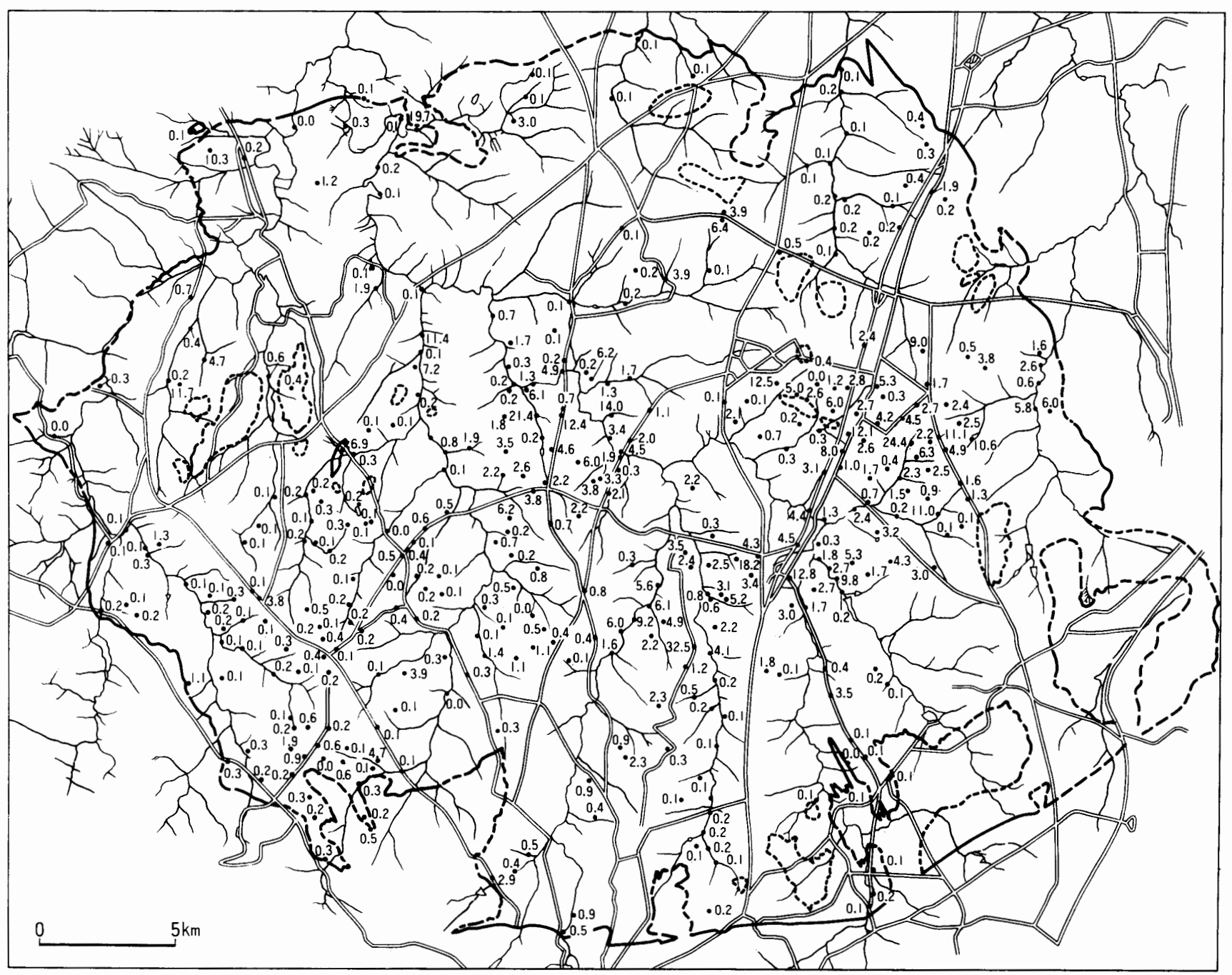

Fig. 3 Localities and magnetic susceptibility values of the granitoids studied on the Johannesburg Dome. The values are in $\times 10^{-3}$ SI units. 


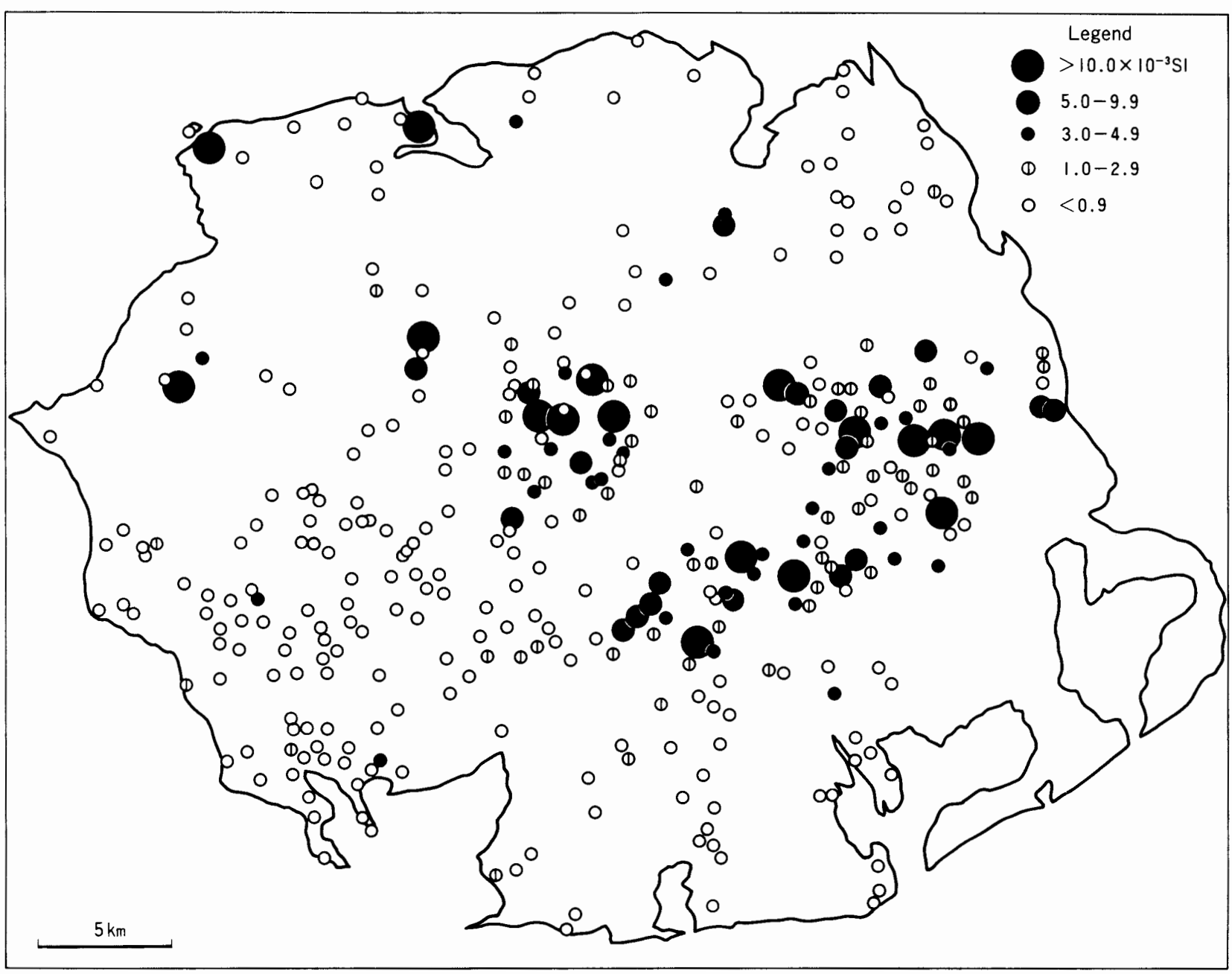

Fig. 4 Sample distribution and intensity of magnetic susceptibility of the Johannesburg Dome granitoids. Solid circles $=$ TTG suite; open circles $=$ calc-alkaline suite .

susceptibility values occur sporadically in the central part of the dome and show an east-west trend (Fig. 4), the latter corresponding with the granitoid rocks grouped within the Transitional Zone.

It is evident in Fig. 4 that low magnetic susceptibility values also occur intimately juxtaposed with high values. This mixed occurrence of high and low values has not been recorded in Phanerozoic island-arc granitoids (such as those of the Japanese Islands) and can be considered as a notable characteristic of the Archaean granitoids investigated in this study, and also in the Kaap Valley pluton of the Barberton region (Ishihara et al., 2001). We need further detailed studies on the contained magnetic minerals.

Magnetic susceptibility data from the Johannesburg Dome granitoids are also shown in histograms in Fig. 5. In this diagram the granitoids are divided into TTG suite and calc-alkaline suite granitoids. The TTG rocks have magnetic susceptibilities of $<0.1-12.8 \mathrm{x}$ $10^{-3}$ SI units. They show mostly ilmenite-series values $(77.9 \%, \mathrm{n}=95$ samples) and partly magnetite-series values $(22.1 \%, \mathrm{n}=27$ samples). The maximum value of $12.8 \times 10^{-3} \mathrm{SI}$ unit is one-third of the values obtained for typical Miocene TTG of the Tanzawa pluton in Japan, which varies from 20 to $50 \times 10^{-3}$ SI unit over a silica range of $59-70 \%$.

The calc-alkaline suite has a wider variation of up to $36.9 \times 10^{-3} \mathrm{SI}$ units, but the general histogram pattern is similar to that of the TTG suite (Fig. 5). The calc-alkaline granitoids are composed mostly of ilmenite-series rocks $(82.8 \%, \mathrm{n}=198$ samples) and lesser magnetite-series rocks ( $17.2 \%, n=41$ samples). Moreover, the intensity of the magnetic susceptibility is lower than that of typical magnetite-series granitoids in Japan and is similar to that of the intermediate series (Ishihara et al., 1984). Thus, the Archaean granitoids of the Johannesburg Dome are generally composed of reduced-species granitoids and locally of intermediate series, a conclusion also supported by the $\mathrm{Fe}_{2} \mathrm{O}_{3} / \mathrm{FeO}$ ratios. 


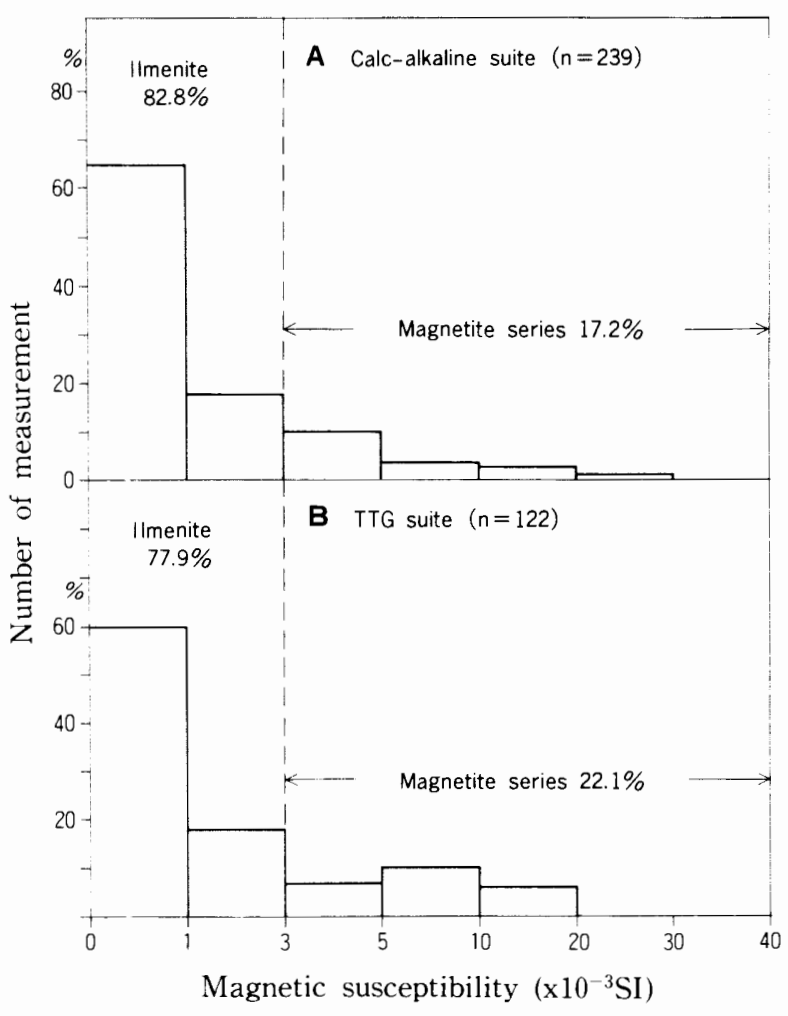

Fig. 5 Histograms of magnetic susceptibility of the Johannesburg Dome granitoids. $A=$ calc$^{-}$alkaline suite; $\mathrm{B}=\mathrm{TTG}$ suite.

\section{Concluding Remarks}

It was found that the majority (c. $80 \%$ ) of the Johannesburg Dome granitic rocks fall into the category of ilmenite-series granitoids. Magnetite-series granitoids, which are intermediate series in a strict sence, also occur sporadically in the central part of the granitic dome. Marginal granitoid rocks, namely those in contact with mafic and ultramafic greenstone remnants are all of the ilmenite-series type. This may imply that the reduced granitic magmas were formed partly as a result of the interaction or assimilation of the mafic-ultramafic country rocks.

It is to be expected that these predominantly volcanic and plutonic rocks were of a reduced nature because the source upper mantle during Archaean times may also have been reduced. For example, Ringwood (1966) estimated $\mathrm{Fe}_{2} \mathrm{O}_{3} / \mathrm{FeO}$ ratios of 0.06 for the pyrolite mantle. Observed $\mathrm{Fe}_{2} \mathrm{O}_{3} / \mathrm{FeO}$ ratios of the Onverwacht Group komatiitic and basaltic komatiitic volcanic rocks of the Barberton greenstone belt range from 0.03 to 0.41 and their averages are 0 . $28(n=14$, Viljoen and Viljoen, 1969b) and $0.21(n=10$, Hawkesworth and O'nions, 1977). Archaean clastic sediments are also reduced, as is shown by $\mathrm{Fe}_{2} \mathrm{O}_{3} / \mathrm{FeO}$ ratios of 0.16 for greywackes and 0.19 for shales of the Fig Tree Group, also in the Barberton greenstone belt (Viljoen and Viljoen, 1969a).

Sporadic magnetite-series granitoids occurring in the central part of the Johannesburg Dome indicate the localized existence of slightly oxidized magmas during this period of early Archaean plutonism. Further detailed studies are needed on the Fe-Ti oxides and mafic silicate minerals in Archaean terranes to understand the genesis of the local $\mathrm{fO}_{2}$ increasings such as that recorded by the Johannesburg Dome granitoids.

Acknowledgment: The first author acknowledges the laboratory assistance given by Dr. Yong YAO during his visit to the Economic Geology Research Institute at the University of the Witwatersrand, Johannesbur$\mathrm{g}$, South Africa, during the summer of 1998. Constructive comments given by Drs. Kohei SATo and Hideo HIRANO are also acnowledged.

\section{References}

Anhaeusser, C. R. (1973) The geology and geochemistry of the Archaean granites and gneisses of the Johannesburg-Pretoria dome. Spec. Publ. Geol. Soc. S. Afr., 3, 361-385.

Anhaeusser, C. R. (1977) Geological and geochemical investigations of the Roodekrans ultramafic complex and surrounding Archaean volcanic rocks, Krugersdorp District. Trans. Geol. Soc. S. Afr., 80, 17-28.

Anhaeusser, C. R. (1978) The geology and geochemistry of the Muldersdrif Complex and surrounding area, Krugersdorp District. Trans. Geol. Soc. S. Afr., 81, 193-203.

Anhaeusser, C. R. (1992) Archaean granite-greenstone relationships on the farm Zandspruit 191-IQ, North Riding area, Johannesburg Dome. S. Afr. J. Geol., 95, 94-101.

Anhaeusser, C. R. (1999) Archaean crustal evolution of the central Kaapvaal Craton, South Africa: evidence from the Johannesburg Dome. S. Afr. J. Geol., 102, 303-322.

Bateman, P. C., Dodge, F. C. W. and Kistler, R. W. (1991) Magnetic susceptibility and relation to initial ${ }^{87} \mathrm{Sr} /{ }^{86} \mathrm{Sr}$ for granitoids of the central Sierra Nevada, California. Jour. Geophy. Res., 96, B12, 19,555-19,568.

Gastil, G., Diamond, J., Knaack, C., Walawender, M., Marshall, M., Boyles, C. and Chadwick, B. (1990) The problems of the magnetite/ilmenite boundary in southern and Baja California, California. In: The Geology of North America. Bull. Geol. Soc. Amer., 174, 19-32.

Hawkesworth, C..J. and O'nions, R.K. (1977) The petrogenesis of some Archean volcanic rocks from southern Africa. Jour. Petrol., 18, 487 -520 .

Ishihara, S. (1977) The magnetite-series and il- 
menite-series granitic rocks. Mining Geol., 27, 293-305.

Ishihara, S. (1979) Lateral variation of magnetic susceptibility of the Japanese granitoids. Jour. Geol. Soc. Japan, 85, 509-523.

Ishihara, S. (1990) The Inner Zone Batholith vs. the Outer Zone Batholith of Japan: Evaluation from their magnetic susceptibilities. Univ. Mus., Univ. Tokyo, Nature \& Culture, 2, 21-34.

Ishihara, S. and Wang, P-A. (1999) The ilmenite -series and magnetite-series classification of the Yanshanian granitoids of South China. Bull. Geol. Surv. Japan, 50, 661-670.

Ishihara, S., Hashimoto, M. and Machida, M. (2000) Magnetite/ilmenite-series classification and magnetic susceptibility of the Mesozoic-Cenozoic batholiths in Peru. Resource Geol., 50 , 123-129.

Ishihara, S., Lee, D. S. and Kim, S. Y. (1981) Comparative study of Mesozoic granitoids and related W-Mo mineralization in southern Korea and southwestern Japan. Mining Geol., 31, 311-320.

Ishihara, S., Sato, K. and Terashima, S. (1984) Chemical characteristics and genesis of the mineralized intermediate-series granitic pluton in the Hobenzan area, western Japan. Mining Geol., 34, 401-418.

Ishihara, S., Wang, P-A. and Watanabe, Y. (2001) The granitoid series and mineralizations at the type locality for the Yanshanian magmatism, north of Beijing, China. Chishitsu News, 565 , p. 24-34 (in Japanese).

Ishihara, S., Robb, L.J., Anhaeusser, C.R. and Imai A. (2001) Granitoid series in terms of magnetic susceptibility: A case study from the Archaean Barberton region, South Africa. Gondowana Res. (Submitted).

Ishihara, S., Sawata, H., Arpornsuwan, S., Busaracome, P. and Bungbrakearti, N. (1979) The magnetite-series and ilmenite-series granitoids and their bearing on tin mineralization, particularly of the Malay Peninsula region. Bull. Geol. Soc. Malaysia, 11, 103-110.
Ishihara, S., Ulriksen, C. E., Sato, K., Terashima, S., Sato, T. and Endo, Y. (1984) Plutonic rocks of North-Central Chile. Bull. Geol. Surv. Japan, 35, 503-536.

Jin, M-S., Lee, Y-S. and Ishihara, S. (2001). Granitoids and their magnetic susceptibility in South Korea. Resource Geol., 51, 189-203.

Kanaya, H. and Ishihara, S. (1973) Regional variation of magnetic susceptibility of the granitic rocks in Japan. Jour. Japan. Assoc. Pet. Min. Econ. Geol., 68, 219-224.

Peacock, M. A. (1931) Classification of igneous rocks. Jour. Geol., 39, 54-67.

Poujol, M. and Anhaeusser, C. R. (2001) The Johannesburg Dome, South Africa: new single zircon $\mathrm{U}-\mathrm{Pb}$ isotopic evidence for early Archaean granite-greenstone development within the central Kaapvaal Craton. Precambrian Res., 108, 139-157.

Ringwood, A. E. (1966) Composition and origin of the earth. In: Hurley P. M. (ed.), Advances in Earth Sciences. MIT Press, Cambridge, 287 -356 .

Robb, L. J. and Anhaeusser, C. R. (1983) Chemical and petrogenetic characteristics of Archaean tonalite-trondhjemite gneiss plutons in the Barberton Mountain Land. Spec. Publ. Geol. Soc. S. Afr., 9, 103-116.

Tainosho, Y., White, A. J. R., Chen, Y. and Wormald, R. (1988) Regional variation of magnetic susceptibility of the Lachlan fold belt granitoids, southeastern Australia. Jour. Geol. Soc. Japan, 94, 657-668.

Viljoen, M.J. and Viljoen, R.P. (1969a) An introduction to the geology of the Barberton granite-greenstone terrain. Spec. Publ. Geol. Soc. S. Afr., 2, 9-28.

Viljoen, R.P. and Viljoen, M.J. (1969b) The geological and geochemical significance of the upper formation of the Onverwacht Group. Spec. Publ. Geol. Soc. S. Afr., 2, 113-151.

Received October 10, 2001

Acceptfd December 20, 2001 
南アフリカの始生代ヨハネスブルグ・ドーム花峒岩体の花崗岩系列からの評価

石原舜三・C. L. アンホイザー・L. L. ロフ

要旨

ヨハネスブルグ・ドーム花崗岩体の酸化/還元状態を，文献による既発表資料の全岩 $\mathrm{Fe}_{2} \mathrm{O}_{3} / \mathrm{FeO}$ 比， およびウィトウオタースランド大学保管の新鮮な花崗岩標本と野外露頭における帯磁率の測定から評価 した.この花崗岩類は 33.4-32.0 億年の年代を持つトロニエム岩ートナル岩一花崗閃緑岩 (TTG) おょ び 31.1 億年の年代を持つカルクアルカリ岩 (アルカリライム指数 $=62.5)$ から構成される. 全岩の $\mathrm{Fe}_{2}$ $\mathrm{O}_{3} / \mathrm{FeO}$ 比は両者とも 0.5 より低いものが多く,チタン鉄鉱系が卓越する傾向を示し, 帯磁率測定の評価 によると, 前者は測定数 122 個のうちチタン鉄鉱系 78\%，磁鉄鉱系 $22 \%$, 後者は測定数 239 個のうちチ タン鉄釷系 $83 \%$, 磁鉄釷系 $17 \%$ の值を示した。磁鉄鉱系の值を示す花崗岩類においても，その帯磁率は 日本の典型的な磁鉄鉱系花崗岩と比較して $1 / 3$ 程度であり，中間系列に属すものである．以上からヨ八 ネスブルグ・ドーム花崗岩類は本来的に還元型のマグマから構成されたと判断される.チタン鉄鉱系の 産状から周縁部ではグリンストンの同化による還元も考えられる．少量の中間系は岩体中心部に分布す る傾向があり，そのような局部的な磁鉄鉱の産出の原因については造岩苦鉄鉱物などについて，今後の 詳細な研究が必要である。 